\title{
FEATURES OF THE INFLUENCE OF HUMAN CAPITAL ON ECONOMIC DEVELOPMENT: THE CASE OF UKRAINE
}

\author{
Andrii Zolkover \\ Kyiv National University of Technologies and Design, Ukraine \\ Anastasiia Kaplina \\ Kherson State Agrarian and Economic University, Ukraine \\ Olena Loboda \\ Kherson State Agrarian and Economic University, Ukraine \\ Natalia Kyrychenko \\ Kherson State Agrarian and Economic University, Ukraine \\ Nataliia Chopko \\ Ivan Franko National University of Lviv, Ukraine
}

\begin{abstract}
The purpose of this article is to substantiate the nature of the relationship between the development of human capital (HC) and the development of the economy of Ukraine. Using the Granger test and cognitive modeling, the features of the development of $\mathrm{HC}$ in modern conditions and its influence on the country's economic development have been determined, and the dominant factors influencing the development and quality of $\mathrm{HC}$ have been empirically substantiated. The ambiguous nature of the influence of $\mathrm{HC}$ on the country's economy due to the inefficiency of spending in the field of education and health care has been established using the impulse modeling method. The positive impact of the development of $\mathrm{HC}$ on the development of the economy is leveled with the growth of investment in education and health care, which is due to the low efficiency of expenditures and the insufficient level of competence of state bodies.
\end{abstract}

Keywords: Human Capital, Economy, Ukraine, Healthcare, Education, Competence, Investment

DOI: http://dx.doi.org/10.15549/jeecar.v8i3.763

\section{INTRODUCTION}

Economic activity is increasingly being transformed into a functioning system based on knowledge exchange and their mutual assessment via creation and dissemination (as a 
resource), knowledge (as the end product of activity), and the modern market economy (Zelinska, Andrusiv \& Simkiv, 2020). HC and its qualitative characteristics began to predetermine the conditions, goals, and driving forces of socio-economic development at the level of global, national and regional economies (Ismayilzade et al., 2021; Karaçor et al., 2019; Bieliński, 2016), and it occupies more than $80 \%$ of the structure of the national wealth of developed countries (Aganbegyan, 2017). The COVID-19 pandemic (which caused a global economic and humanitarian crisis due to the pressures it put on healthcare systems and the disruptions it caused in numerous trade supply chains) (Megits, Neskorodieva \& Schuster, 2020) only strengthened the requirements for the quality and importance of $\mathrm{HC}$ for the development of an economy and ensuring its sustainability.

According to international rating indicators, the most competitive criteria of the knowledge economy in Ukraine are HC, higher education, and knowledge and research results (Zelinska, Andrusiv \& Simkiv, 2020). Attention to HC in Ukraine is insufficient, however, as evidenced by a higher level of sensitivity of social as compared to economic indicators during the crisis (in 2015, while GDP decreased by $9.8 \%$, consumer spending decreased by 15\%) (State Statistics Service of Ukraine, 2021). Despite the government's efforts, the Ukrainian economy is characterized by the lowest GDP per capita among the countries of Central and Eastern Europe (20\% of the EU average) (The World Bank Group, 2021b). To leading experts, one of the main reasons for this situation is the unrealized potential of human resources in the country. With the existing level of investment in the development of education and healthcare, a modern Ukrainian child has the potential to achieve $63 \%$ of the productivity of an adult with complete education and an optimal state of health (The World Bank Group, 2020). The level of investment in the development of the HC did not improve from 2010 to 2020 in Ukraine (The World Bank Group, 2021a). This lack of investment has limited productivity growth (less than $10 \%$ of the EU average) (OECD, 2021a), private-sector job creation, and improved living standards despite the country's highly skilled workforce. As a result, many workers are looking for work abroad. The quality of HC (knowledge, skills, and health that people accumulate during their lives) is of course influenced by many factors (Ismayilzade et al., 2021; Zheng \& Lu, 2020; Pirtskhalaishvili, Paresashvili \& Kulinich, 2021). Therefore, this study is aimed to determine the features of the influence of $\mathrm{HC}$ on the development of the Ukrainian economy, accounting for the current level of development of education and healthcare.

\section{LITERATURE REVIEW}

The features of the qualitative parameters of $\mathrm{HC}$ in different countries of the world and development factors were presented in the World Economic Forum report "Human capital in 2013" (World Economic Forum, 2013). Based on this report, most scholars adhere to the point of view that education and healthcare directly impact the development of $\mathrm{HC}$ and economic growth, regardless of the level of development of the country's economy (Zheng \& Lu, 2020). A debatable issue, though, is the assessment of the social impact of HC. In OECD countries, an additional year of study increases labor productivity in the medium and long term by 47\% (OECD, 2001). Many EU countries, notably the UK, have seen a steady rise in the relative salary of university graduates (High Fliers Research, 2021). This can be explained both by the progress of technology, stimulating the demand for tertiary education, and a decrease in the share of wages of unskilled workers due to the transfer of industries that do not require high qualifications to developing countries (Kupets, 2016). Because of this, the assessment of the importance of education as a factor in the quality of $\mathrm{HC}$ presented in modern research seems inaccurate. The monetary measurement - the financial return of education for an individual - is important. (Psacharopoulos \& Patrinos, 2018). But in a globalized and innovative economy, the country wins if the population is predominantly employed in skilled labor (Zhao, 2020). It also is obvious that knowledge, skills, and competence increase productivity, the ability of the economy to develop and use the latest technologies. As a result, Ukraine's competitiveness in the international arena is increasing. Moreover, not only higher, but also specialized secondary education, is important. The latter is especially true for Ukraine, where the system of secondary 
specialized education has been practically destroyed (Friedman \& Trines, 2019).

Scholars argue about a directly proportional relationship between the development of healthcare and the economy. For example, a study of Trinidad and Tobago found that an increase in investment of $1 \%$ in healthcare increased the level of foreign direct investment in the economy after 2 years by $3 \%$ (Alsan, Bloom \& Canning, 2006). And in Mexico, it was found that for 1970-1995 1/3 of the country's economic growth was ensured by an improvement in the population's health status (Márti, 2004). Chinese scholars have determined that productivity levels, increasingly determined by workers' health, will become the backbone of economic growth over the next 15 years. In Ukraine's case, a significant share of GDP (4.6\%) has been directed to the health sector (State Statistics Service of Ukraine, 2021). In the economic literature, health care in Ukraine is considered as a non-production sphere that does not participate in the creation of the national income but only consumes it (Romaniuk \& Semigina, 2018). Therefore, the peculiarity of resource formation in the health sector is carried out according to the "residual" principle of financing. All of this has provoked low efficiency using resources and an unprofessional attitude of medical workers to their duties, and corruption. These disadvantages are associated with the fact that healthcare, like other service industries, has an economic origin (Habibov, 2016).

Thus, the modern scientific literature reflects the variety of benefits from improving the quality of $\mathrm{HC}$, however, this knowledge has not been transformed to something geared to help a country's development. In many ways, the obstacle has been the lack of convincing data that would clearly demonstrate the profitability of investing in $\mathrm{HC}$.

\section{METHODS AND MATERIALS}

Cognitive modeling was used to assess the impact of $\mathrm{HC}$ on the economic development of Ukraine. To implement the method, fuzzy cognitive maps, which are econometric models like in a directed graph, were built, (Gorelova, Pankratova \& Borisova, 2019). From this, a sample of indicators of the development of $\mathrm{HC}$ and the economy for 2010-2020 was formed.

In determining the indicators that affect $\mathrm{HC}$ development, the cost-based approach (Trovato, 2020) and the indicators-based approach of Abdelmajied \& Safijllin (2018), Ismayilzade et al. (2021), Megits, Neskorodieva and Schuster (2020), Zheng and Lu (2020) have been used. The State Statistics Service of Ukraine (2021) and The World Bank Group (2021a) were used as an informative base.

Table 1: Indicators for assessing the impact of $\mathrm{HC}$ on economic development

\begin{tabular}{|l|c|}
\hline \multicolumn{1}{|c|}{ Indicators } & Symbols \\
\hline Number of postgraduate students, ppl. & E1 \\
\hline Number of doctoral students, ppl. & E2 \\
\hline Number of first-year students in tertiary education, thsd. ppl. & E3 \\
\hline Number of people who graduated university, thsd. ppl. & E4 \\
\hline Number of universities, un. & E6 \\
\hline Number of students in tertiary education, thsd. ppl. & E7 \\
\hline Number of institutions of preschool education, thsd. & E8 \\
\hline Number of organizations of professional (vocational and technical) education, un. & E9 \\
\hline Number of students, trainees in vocational education organizations, thsd. ppl. & E10 \\
\hline $\begin{array}{l}\text { Number of first-year students in organizations of professional (vocational) education, } \\
\text { thsd. ppl. }\end{array}$ & E11 \\
\hline $\begin{array}{l}\text { Number of people who graduated organizations of professional (vocational) } \\
\text { education, thsd. ppl. }\end{array}$ & E12 \\
\hline Number of general secondary education organizations, un. & E13 \\
\hline Number of students in general secondary education organizations, ppl. & \\
\hline
\end{tabular}


Table 1: Continued.

\begin{tabular}{|c|c|}
\hline Number of teachers in general secondary education organizations, ppl. & E14 \\
\hline Number of doctors of all specialties (excluding dentists), thsd. ppl. & H1 \\
\hline Number of nursing staff, thsd. ppl. & $\mathrm{H} 2$ \\
\hline Number of hospitals, thsd. un. & H3 \\
\hline Number of hospital beds, thsd. & $\mathrm{H} 4$ \\
\hline Number of medical outpatient clinics, thsd. & $\mathrm{H} 5$ \\
\hline $\begin{array}{l}\text { Index of Human Capital per Person was used to reflect the level of development of } \\
\text { the HC }\end{array}$ & HC1 \\
\hline GDP, UAH million & 01 \\
\hline Household Income, UAH million & $\mathrm{O} 2$ \\
\hline Consumer Spending, UAH million & $\mathrm{O} 3$ \\
\hline Domestic Savings, UAH million & 04 \\
\hline Foreign Direct Investment, mln USD & 05 \\
\hline Exchange rate (USD / UAH) & 06 \\
\hline International reserves (end of the period) $\mathrm{mln}$ USD & 07 \\
\hline Consumer price index (previous year) \% & O8 \\
\hline Capital investments, UAH million & 09 \\
\hline State budget revenues excluding transfers, UAH million & 010 \\
\hline State budget expenditures, UAH million & 011 \\
\hline Lending to the state budget, UAH mln. & 012 \\
\hline Financing of the state budget ("+" deficit / "-" surplus), UAH mln. & 013 \\
\hline Registered Unemployed (end of the period) thsd. ppl. & 014 \\
\hline Wage arrears, UAH million & 015 \\
\hline The volume of industrial products sold, UAH million & 016 \\
\hline Exports, mln USD & 017 \\
\hline Import, mln USD & 018 \\
\hline Employment rate by age group $15-70$, thsd. ppl & 019 \\
\hline Health and Medical Average Salaries, UAH & $\mathrm{O} 20$ \\
\hline Population, thsd. ppl. & 021 \\
\hline Migration (inflow “+” / outflow “-”), thsd. & 022 \\
\hline
\end{tabular}

Source: Authors' finding

To assess the impact of HC on the country's economic development, a fuzzy cognitive map was used, a formalized description of which, taking into account the field of study, has the form (Gorelova, Pankratova \& Borisova, 2019):

$C M=\langle E, H, H C 1, O, F, W\rangle$

where $C M$ - formalized description of a fuzzy cognitive map;

$E$ - indicators of the costs and investments on development of $\mathrm{HC}$ with accounting develop a level of education;

$\mathrm{H}$ - indicators of the development of HC with accounting develop a level of healthcare

HC1 - Index of Human Capital per Person;

$\mathrm{O}$ - indicators of economic development;

$F$ - indicators relationship;
$W$ - Weights of arcs reflecting the tightness of the relationship between indicators.

The assessment of the influence of $\mathrm{HC}$ on economic development was carried out in the following stages:

1) calculated paired correlation coefficients between indicators affecting the development of HC, Index of Human Capital per Person as indicators of economic development;

2 ) established the direction of cause-and-effect relationships between indicators using the Granger test. The stationary nature of the data was confirmed by the extended DickeyFuller test using the EViews 10 program;

3 ) based on statistically significant (at p $=0.05$ ) causal relationships, cognitive maps were 
built and system indicators of cognitive maps were calculated (Outdegree, Indegree, Centrality), for which Mental Modeler software was used. Outdegree is a function that reflects the influence of $\mathrm{HC}$ and the formation factor, indicators of Ukraine's economic development on each other. The higher the consonance score, the more significant the impact. Dissonance (Indegree) is a function of the absence of influence between indicators. The influence of concepts (indicators) on the system (Centrality) reflects the maximum positive or negative influence of $\mathrm{HC}$ on the economic development (Gorelova, Pankratova \& Borisova, 2019);

4) using the method of impulse modeling implemented in the Mental Modeler program, the change in economic development indicators with accounting growth of the Index of Human Capital per Person indicator and the priority factors of HC formation by $0.1 \%$ was estimated. The criterion for prioritizing factors was maximizing the Centrality and Outdegree values for these factors (Gorelova, Pankratova \& Borisova, 2019).

\section{RESULTS}

The matrix of the calculated pairwise correlation coefficients between the indicators of the development of the $\mathrm{HC}$ and the economy (Table 2) testify to the presence/absence, direct or reverse of links between the indicators.

Table 2: Matrix of the mutual influence of indicators of the development of the HC and Ukraine's economy

\begin{tabular}{|c|c|c|c|c|c|c|c|c|c|c|c|c|c|c|c|c|c|c|}
\hline & O1 & O2 & O3 & O4 & O5 & O6 & O7 & O8 & O9 & $\ldots$ & O16 & $\ldots$ & E1 & $\ldots$ & E14 & HC1 & H1 & $\ldots$ \\
\hline 01 & 1.00 & & & & & & & & & $\ldots$ & & $\ldots$ & & $\ldots$ & & & & $\ldots$ \\
\hline O2 & 0.99 & 1.00 & & & & & & & & $\ldots$ & & $\ldots$ & & $\ldots$ & & & & $\ldots$ \\
\hline O3 & 0.99 & 1.00 & 1.00 & & & & & & & $\ldots$ & & $\ldots$ & & $\ldots$ & & & & $\ldots$ \\
\hline O4 & -0.61 & -0.54 & -0.54 & 1.00 & & & & & & $\ldots$ & & $\ldots$ & & $\ldots$ & & & & $\ldots$ \\
\hline O5 & 0.60 & 0.63 & 0.63 & 0.00 & 1.00 & & & & & $\ldots$ & & $\ldots$ & & $\ldots$ & & & & $\ldots$ \\
\hline O6 & 0.89 & 0.82 & 0.82 & -0.75 & 0.28 & 1.00 & & & & $\ldots$ & & $\ldots$ & & $\ldots$ & & & & $\ldots$ \\
\hline O7 & 0.00 & 0.00 & 0.00 & 0.32 & 0.00 & -0.24 & 1.00 & & & $\ldots$ & & $\ldots$ & & $\ldots$ & & & & $\ldots$ \\
\hline O8 & 0.00 & 0.00 & 0.90 & -0.88 & -0.50 & -0.72 & -0.64 & 1.00 & & $\ldots$ & & $\ldots$ & & $\ldots$ & & & & $\ldots$ \\
\hline O9 & 0.96 & 0.94 & 0.94 & -0.62 & 0.68 & 0.83 & 0.00 & 0.00 & 1.00 & $\ldots$ & & $\ldots$ & & $\ldots$ & & & & $\ldots$ \\
\hline O16 & 0.99 & 0.96 & 0.96 & -0.66 & 0.61 & 0.92 & 0.00 & 0.00 & 0.97 & $\ldots$ & 1.00 & $\ldots$ & & $\ldots$ & & & & $\ldots$ \\
\hline E1 & -0.84 & -0.78 & -0.78 & 0.69 & -0.40 & -0.92 & 0.46 & -0.22 & -0.81 & $\ldots$ & -0.88 & $\ldots$ & 1.00 & $\ldots$ & & & & $\ldots$ \\
\hline E14 & -0.88 & -0.81 & -0.81 & 0.80 & -0.28 & -0.99 & 0.24 & -0.21 & -0.84 & $\ldots$ & -0.91 & $\ldots$ & 0.89 & $\ldots$ & 1.00 & & & $\ldots$ \\
\hline HC1 & 0.94 & 0.92 & 0.92 & -0.72 & 0.50 & 0.91 & -0.30 & 0.00 & 0.89 & $\ldots$ & 0.94 & $\ldots$ & -0.93 & $\ldots$ & -0.91 & 1.00 & & $\ldots$ \\
\hline H1 & -0.73 & -0.67 & -0.67 & 0.63 & -0.20 & -0.87 & 0.62 & -0.48 & -0.64 & $\ldots$ & -0.75 & $\ldots$ & 0.93 & $\ldots$ & 0.85 & -0.88 & 1.00 & $\ldots$ \\
\hline
\end{tabular}

Source: Authors' finding

There is a close direct relationship between the level of $\mathrm{HC}$ development (HC1 indicator) and GDP (O1 indicator), which suggests that HC development has a stimulating effect on economic growth (Table 2). The relationships between the HC1 indicator and the population's income (02), expenditures, and savings of households (03) are also similar in strength and nature. A more qualified $\mathrm{HC}$ with higher indicators of labor productivity has a higher level of remuneration, which leads to an increase in the population's income and expenses, and savings. The development of $\mathrm{HC}$ has a positive effect on the volume of products sold due to the growth in labor productivity. But a situation is possible in which the growth of the Index of 
Human Capital per Person is a consequence of the growth of income and expenditures of the population and an increase in capital investments, which are directed to the development of $\mathrm{HC}$. The Granger test and the extended Dickey-Fuller test were used (Table 3).

Table 3: Results of checking the stationarity of indicators of the development of the $\mathrm{HC}$ and the economy according to the extended Dickey-Fuller test

\begin{tabular}{|c|c|c|c|c|c|}
\hline Indicators & Specification & Prob. & Indicators & Specification & Prob. \\
\hline$E 1$ & $I, 1$ & 0.0013 & 02 & $I, 1$ & 0.0000 \\
\hline$E 2$ & $I, 0$ & 0.0206 & 03 & $I, 1$ & 0.0006 \\
\hline$E 3$ & $I, 0$ & 0.0031 & 04 & $I, 0$ & 0.0000 \\
\hline$E 4$ & $I, 2$ & 0.0055 & 05 & $I, 1$ & 0.0005 \\
\hline$E 5$ & $I, 0$ & 0.0008 & 06 & $I, 0$ & 0.0004 \\
\hline$E 6$ & $I, 1$ & 0.0097 & $O 7$ & $I, 0$ & 0.0001 \\
\hline$E 7$ & $I, 1$ & 0.0010 & 08 & $I, 1$ & 0.0000 \\
\hline$E 8$ & $I, 1$ & 0.0015 & 09 & $I, 0$ & 0.0005 \\
\hline$E 9$ & $I, 1$ & 0.0000 & 010 & $I, 1$ & 0.0082 \\
\hline$E 10$ & $I, 0$ & 0.0076 & 011 & $I, 1$ & 0.0022 \\
\hline$E 11$ & $I, 1$ & 0.0003 & 012 & $I, 0$ & 0.0000 \\
\hline$E 12$ & $I, 0$ & 0.0009 & 013 & $I, 0$ & 0.0000 \\
\hline$E 13$ & $I, 1$ & 0.0384 & 014 & $I, 0$ & 0.0012 \\
\hline$E 14$ & $I, 0$ & 0.0005 & 015 & $I, 0$ & 0.0232 \\
\hline$H 1$ & $I, 1$ & 0.0007 & 016 & $I, 0$ & 0.0003 \\
\hline$H 2$ & $I, 0$ & 0.0004 & 017 & $I, 0$ & 0.0215 \\
\hline$H 3$ & $I, 0$ & 0.0000 & 018 & $I, 0$ & 0.0037 \\
\hline$H 4$ & $I, 0$ & 0.0028 & 019 & $I, 1$ & 0.0081 \\
\hline$H 5$ & $I, 0$ & 0.0083 & 020 & $I, 0$ & 0.0044 \\
\hline$H C 1$ & $I, 1$ & 0.0301 & 021 & $I, 1$ & 0.0003 \\
\hline$O 1$ & $I, 0$ & 0.0014 & $O 22$ & $I, 1$ & 0.0005 \\
\hline
\end{tabular}

Source: Authors' finding

Prob. - the probability of accepting the null hypothesis that the time series is non-stationary;

I - constant model specification;

0 - corresponds to the specification when the time series is stationary without transformations;

1 - corresponds to the specification where the stationarity of the time series is ensured by first-order integration.

According to Table 3, the probability of accepting the null hypothesis that the time series nonstationary did not exceed $3.84 \%$. This allows the conclusion that at a significance level of 0.05 , all indicators E1-E14, H1-H5, HC1, 01-O22 are stationary, and the Granger test can be applied to them.

Using the Granger test, statistically significant cause-and-effect relationships between the indicators of the development of $\mathrm{HC}$ and the economy were determined. Cause-and-effect relationships were accepted as significant, for which the values of the probabilities of accepting the null hypothesis (about the non-statistical significance of the relationship) did n'|ot exceed 0.05 (Contreras-Reyes \& Hernández-Santoro, 2020). These connections have been reflected in cognitive maps.

The constructed fuzzy cognitive judgment of the influence of $\mathrm{HC}$ on economic development, taking into account the influence of the factors of HC, contains 42 indicators for assessing the influence and 465 connections. Estimates of the impact of $\mathrm{HC}$ on economic development were obtained due to the automatic structural analysis of the cognitive map in the Mental Modeler program (Table 4 ). 
Table 4: Formalization of indicators of economic development taking into account HC factors

\begin{tabular}{|c|c|c|c|c|c|c|c|c|c|}
\hline Indicators & Indegree & Outdegree & Centrality & Type & Indicators & Indegree & Outdegree & Centrality & Type \\
\hline 01 & 12.26 & 18.55 & 26.57 & \multirow{7}{*}{ ordinary } & 022 & 8.13 & 4.04 & 7.93 & \multirow{21}{*}{ ordinary } \\
\hline $\mathrm{O} 2$ & 18.13 & 8.99 & 22.88 & & HC1 & 20.63 & 9.31 & 25.70 & \\
\hline $\mathrm{O3}$ & 10.45 & 16.67 & 22.88 & & E1 & 27.44 & 4.20 & 27.40 & \\
\hline 04 & 9.30 & 12.40 & 17.46 & & E2 & 15.38 & 5.59 & 16.73 & \\
\hline 05 & 1.60 & 10.66 & 8.02 & & E3 & 22.98 & 6.44 & 25.18 & \\
\hline 06 & 5.26 & 26.31 & 27.33 & & E4 & 25.25 & 5.71 & 26.72 & \\
\hline 07 & 1.02 & 6.70 & 7.72 & & E5 & 23.39 & 6.14 & 25.29 & \\
\hline 08 & 0 & 5.63 & 5.63 & driver & E6 & 22.29 & 8.51 & 26.56 & \\
\hline 09 & 7.40 & 19.97 & 23.13 & \multirow{13}{*}{ ordinary } & E7 & 14.79 & 10.71 & 21.26 & \\
\hline 010 & 22.71 & 6.83 & 25.30 & & E8 & 19.19 & 12.04 & 26.99 & \\
\hline 011 & 13.51 & 14.47 & 23.74 & & E9 & 19.67 & 11.22 & 26.65 & \\
\hline 012 & 1.10 & 2.38 & 3.48 & & E10 & 18.69 & 12.03 & 26.48 & \\
\hline 013 & 4.11 & 10.86 & 10.73 & & E11 & 21.26 & 9.65 & 26.67 & \\
\hline 014 & 6.72 & 21.16 & 23.64 & & E12 & 17.91 & 12.64 & 26.31 & \\
\hline 015 & 4.00 & 23.14 & 22.90 & & E13 & 10.31 & 12.89 & 18.96 & \\
\hline 016 & 6.46 & 23.61 & 25.83 & & E14 & 15.10 & 13.97 & 24.83 & \\
\hline 017 & 4.16 & 17.85 & 17.76 & & $\mathrm{H} 1$ & 13.83 & 16.37 & 25.96 & \\
\hline 018 & 4.65 & 8.68 & 9.09 & & $\mathrm{H} 2$ & 13.60 & 19.02 & 32.62 & \\
\hline 019 & 9.98 & 20.45 & 26.19 & & $\mathrm{H} 3$ & 11.87 & 18.44 & 26.07 & \\
\hline $\mathrm{O} 20$ & 5.08 & 29.48 & 28.56 & & $\mathrm{H} 4$ & 16.56 & 15.72 & 32.28 & \\
\hline 021 & 9.23 & 21.77 & 26.76 & & $\mathrm{H} 5$ & 21.33 & 1.52 & 18.61 & \\
\hline
\end{tabular}

Source: Authors' finding

Indicator (08) for the "Driver" type affects others (indicators of economic development) and is not influenced by any of them. The consumer price index $(08)$ has a destabilizing effect on the exchange rate (06), international reserves (07), and financing of the state budget (013), leads to an increase in household spending (03), wage arrears (015), and a decrease in savings (04), which is due to a decrease in real incomes of the population and other cost indicators. The significant impact of the consumer price index on GDP and household income is not deterministic, and nominal values of these indicators were used;

22 indicators of economic development, 5 indicators of medical support, and 14 indicators reflecting the sphere of education have formed the "Ordinary" type. These are intermediate indicators that affect some indicators and are influenced by others.

Based on the analysis results (Table 4), the most significant indicators of the impact on the development of $\mathrm{HC}$ and the Ukrainian economy have been determined. These are indicators of the number of nursing staff $(\mathrm{H} 2)$ and the number of hospital beds (H4), which have the highest values of the Centrality indicator. These are the indicators that have the most significant impact on HC formation and largely depend on the indicators of economic development. The difference in the value of "Centrality" for indicators $\mathrm{H} 2$ and $\mathrm{H} 3$ is $1.05 \%$, which indicates an almost equal degree of their influence on the development of the $\mathrm{HC}$ and the economy. For the next most influential indicator (020), the Centrality value is $13.03 \%, 14.22 \%$ lower compared to $\mathrm{H} 4$ and $\mathrm{H} 2$, respectively. But this indicator has the highest "Outdegree" value (29.48). This means that the indicator of the average monthly salary of medical workers is the largest among the studied population and is subject to the influence of other indicators. For other indicators, the impact on human capital development and the economy is not so significant, and other indicators do not so much influence them themselves. In this regard, to model changes in economic development indicators under the influence of $\mathrm{HC}$, indicators $\mathrm{H} 2, \mathrm{H} 4, \mathrm{O} 20$ were used as controllable factors. It was assumed that these indicators will increase 
by $0.1 \%$ (Fig. 1 ).

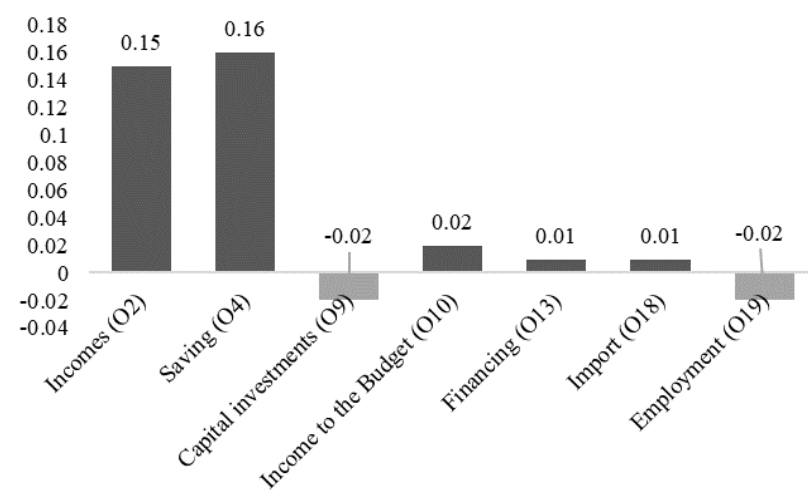

Figure 1a: Increase of the number of nurses by $0.1 \%$

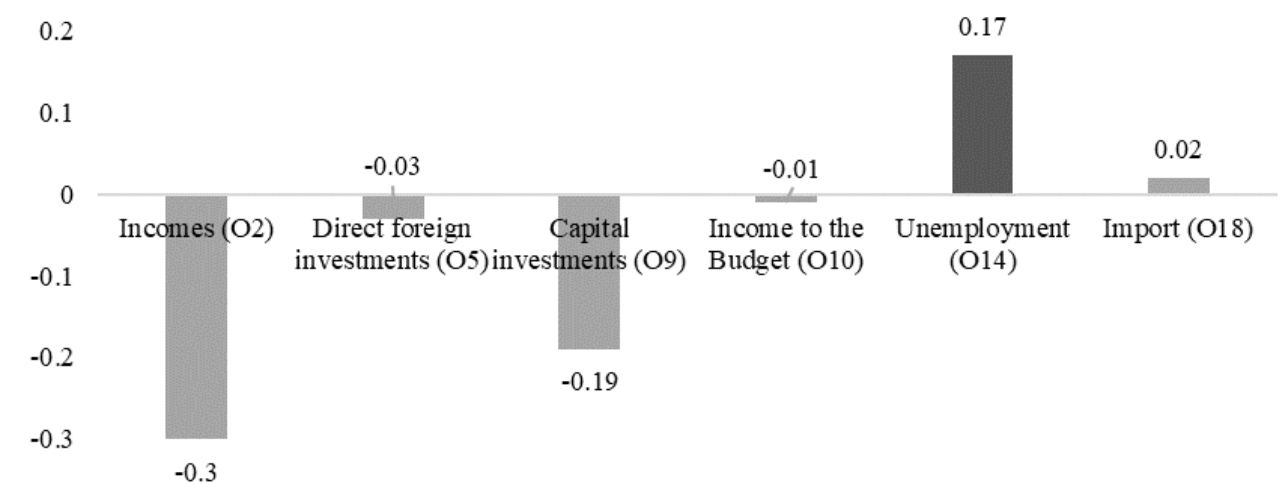

Figure 1c: Increase in the average salary of medical personnel by $0.1 \%$

Figure 1: Assessment of changes in economic development indicators with accounting the development of the $\mathrm{HC}$

Source: Authors' finding

The negative impact of the COVID-19 pandemic has formed a pool of negative effects for the country's economic development and generated an increasing need for medical care. According to Fig. 1a, an increase in the number of paramedical personnel by $0.1 \%$ and the total wages of this category of employed causes an increase in household incomes by $0.15 \%$, savings by $0.16 \%$, and state budget revenues by $0.02 \%$ due to an increase in tax payments. The increase in income impacts directly on consumption, contributing to the growth of imports. But, the increase in the number of medical personnel provokes the need for an increase in budget funding by $0.1 \%$ to cover the corresponding costs of retaining this category of personnel; reduction

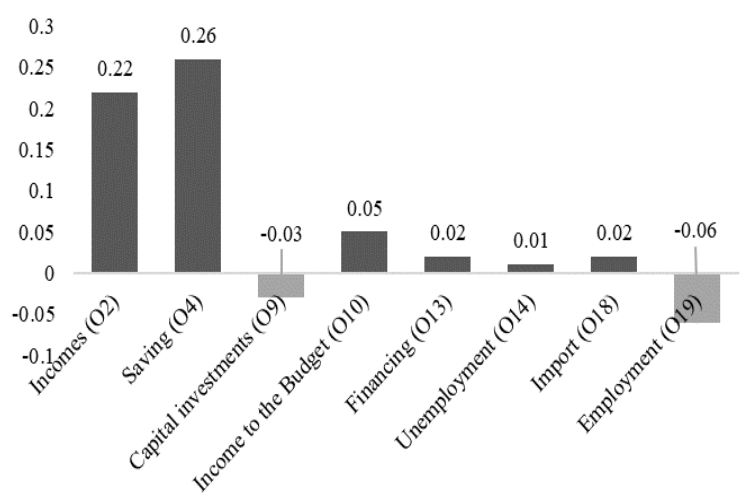

Figure 1b: Increase of the number of nurses and the hospital beds by $0.1 \%$ 
of nurses and the number of hospital beds is the growing need for financing healthcare and the lack of funding for other sectors, which leads to a decrease in capital investment and an increase in unemployment.

The need to develop medical support is associated with the increase in salaries in healthcare. This is especially true in the context of the COVID-19 pandemic; during 2020-2021, doctors were provided with additional payments, and a further increase in the minimum wage for this category of workers is expected (Interfax, 2021). Under decreases in production and a decrease in income in the service sector during a pandemic, a decrease in the financial capabilities of state support for SMEs decreases jobs and an increase in the number of unemployed by $0.17 \%$ (Fig. 1c). An increase in the salary of medical employments by $0.1 \%$ leads to a decrease in the population's income by $0.3 \%$, which is natural with a given increase in unemployment. Other negative manifestations of the growth of salaries of medical personnel are a decrease in state budget revenues by $0.01 \%$, in capital investments by $0.19 \%$, and in foreign direct investment by $0.03 \%$ as a result of a decrease in the country's investment attractiveness.

The second model was built (Fig. 2), in which the Index of Human Capital per Person represents a concept of the "Driver" type. This indicator affects other indicators of economic development and is not influenced by any of them. Due to this, it is possible to assess the impact of the development of $\mathrm{HC}$ on the country's economy. The direction of the arc in Fig. 2 indicates the direction of influence between indicators. The +/- sign reflects a positive or negative relationship.

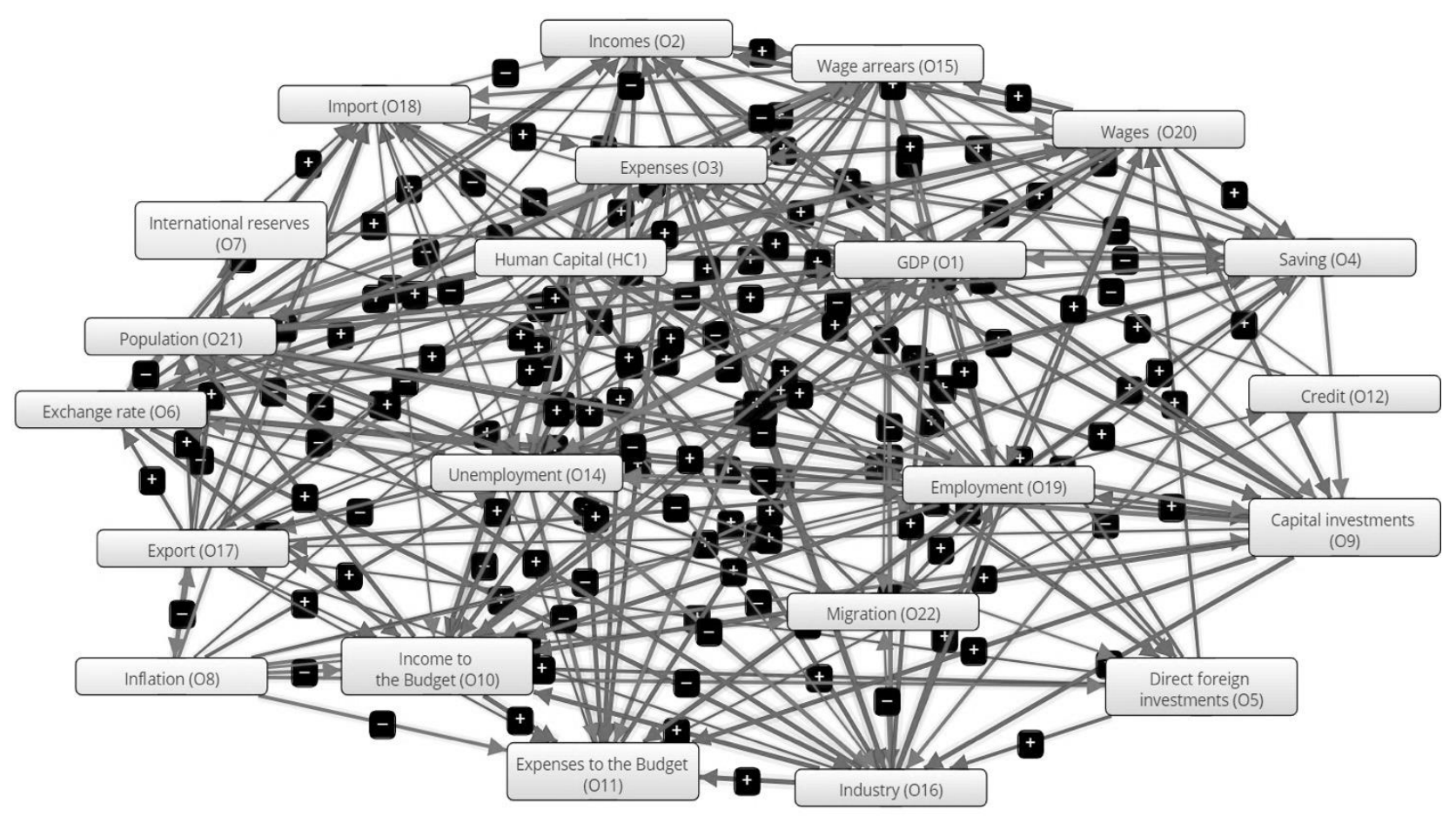

Figure 2: Cognitive map for assessing the impact of the HC on the economic development of Ukraine Source: Authors' finding

To assess the influence of $\mathrm{HC}$ on the components of economic development (without factors of development of $\mathrm{HC}$ ), the most significant concepts of the model were determined (Table 5). 
Table 5: Formalization indicators of economic development, taking into account the development of $\mathrm{HC}$

\begin{tabular}{|c|c|c|c|c|c|c|c|c|c|}
\hline Component & Indegree & Outdegree & Centrality & Type & Component & Indegree & Outdegree & Centrality & Type \\
\hline HC1 & 0.00 & 14.16 & 14.16 & driver & 08 & 0.64 & 5.86 & 6.5 & ordinary \\
\hline O1 & 14.61 & 0.00 & 14.61 & receiver & 09 & 5.59 & 7.73 & 13.32 & ordinary \\
\hline O2 & 6.98 & 5.86 & 12.84 & ordinary & 011 & 9.56 & 2.26 & 11.82 & ordinary \\
\hline O3 & 6.98 & 5.84 & 12.82 & ordinary & 012 & 0.74 & 0.69 & 1.43 & ordinary \\
\hline O4 & 6.90 & 3.73 & 10.63 & ordinary & 014 & 6.19 & 8.83 & 15.02 & ordinary \\
\hline O5 & 2.56 & 3.13 & 5.69 & ordinary & 015 & 5.76 & 8.25 & 14.01 & ordinary \\
\hline O6 & 5.48 & 7.82 & 13.30 & ordinary & 016 & 7.27 & 7.42 & 14.69 & ordinary \\
\hline O7 & 0.38 & 1.78 & 2.16 & ordinary & 017 & 2.75 & 7.31 & 10.06 & ordinary \\
\hline
\end{tabular}

Source: Authors' finding

The HC level (HC1); "Receiver" - GDP (01), was defined, which is influenced by all factors but does not affect other factors; "Ordinary" are concepts that reflect the components of economic development. Based on the results of the analysis of Table 5 and the constructed cognitive map (Fig. 2), the changes in the parameters of economic development have been estimated, taking into account the growth of $\mathrm{HC}$ by $0.1 \%$ (Fig. 3 ).

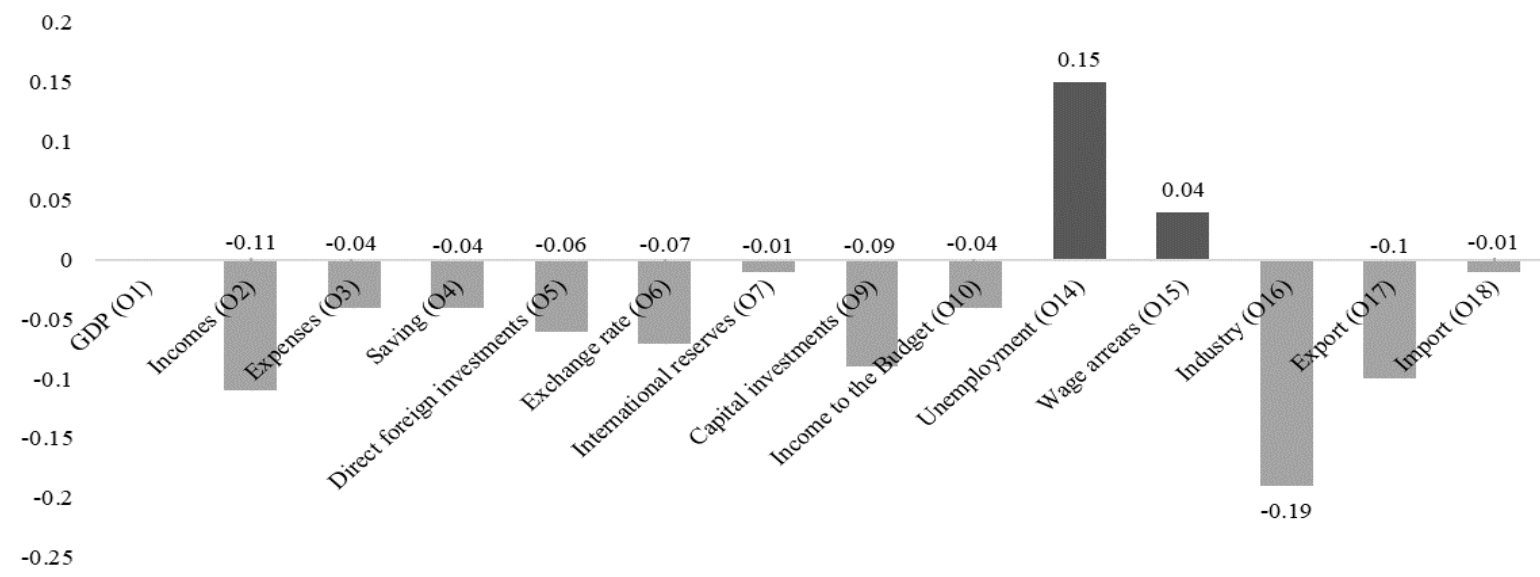

Figure 3: Assessment of changes in economic development under increasing the Index of Human Capital per Person by $0.1 \%$

Source: Authors' finding

\section{DISCUSSION AND CONCLUSION}

In this study, the influence of development indicators was assessed only in education and healthcare since today these are the fundamental spheres of the economy that have a decisive influence on the quality of human capital, according to the Index of Human Capital per Person (Our World In Data, 2021). There is a close direct relationship between the Index of Human Capital per Person and the volume of GDP (the value of the pair correlation coefficient is 0.94). The presence of a causal relationship between these indicators was evidenced by the results of the Granger test, according to which the statistically significant influence of the Index of Human Capital per Person indicator on GDP is confirmed with a probability of $99 \%$. At the same time, the change in the Index of Human Capital per Person does not lead to changes in the GDP. The growth of the Index of Human Capital per Person hurts other indicators of economic development. With an increase in the Index of Human Capital per Person indicator by $0.1 \%$, there is a decrease in household income by $0.11 \%$, 
expenses by $0.04 \%$, savings by $0.04 \%$, foreign direct investment by $0.06 \%$, capital investments by $0.09 \%$, state budget revenues by $0.04 \%$, volumes of industrial products sold by $0.19 \%$, exports by $0.1 \%$, imports by $0.01 \%$, an increase in wage arrears by $0.04 \%$, an increase in the number of unemployed by $0.15 \%$, devaluation of the hryvnia exchange rate by $0.07 \%$, and a decrease in international reserves by $0.01 \%$. The results obtained are explained by the fact that $\mathrm{HC}$ development has a positive effect on GDP. But considering the costs of education and medicine (which are factors in the formation of $\mathrm{HC}$ ) at a given level of development of these factors, the positive influence of HC on GDP is leveled. The COVID-19 pandemic also aggravates the economic situation. The need for financing the health care system increases with a decrease in GDP (in 2020, GDP in constant prices decreased by $4 \%$ compared to 2019 . (State Statistics Service of Ukraine, 2021).

The current paradoxical situation in Ukraine, when an increase in the level of investment in the health care and education systems has a destructive effect on the development of the economy, contradicts the concept of the dependence of the level of human capital development and economic growth (Ismayilzade et al., 2021; Zheng \& Lu, 2020; Karaçor et al., 2019). As the study shows, the factor that determines HC development today is the development of healthcare in Ukraine. In 2019, state funding for healthcare was practically at the level of 1991. But at the same time, total expenditures (taking into account private expenditures of citizens) on healthcare in Ukraine are comparable to the average for the EU and in reference countries and amount to $8.6 \%$ of GDP (State Statistics Service of Ukraine, 2021). About $58 \%$ of all healthcare expenditures in Ukraine are private household expenditures (Beley, Kudlatsky \& Kovalev, 2020). In turn, the lack of funding leads to a shortage of personnel, an increased burden on doctors, and, most importantly, inequality in access to quality health care in different regions. But according to the results of the study, an increase in funding will not have a positive impact on $\mathrm{HC}$ and economic growth. A very low efficiency of public and private spending in healthcare and a high level of corruption can be stated. Therefore, as a factor quality of $\mathrm{HC}$, the fundamental goal of healthcare should be the principle "money follows the patient," as then there will be incentives for healthy competition and improved quality of services. Strictly targeted use of funds allocated by the state to purchase priority services are linked to causes of death, so therefore introduce a permanent system for monitoring the qualitative and quantitative indicators of the provision of medical care and the implementation of medical protocols focusing on assessing the correct use of medicines and medical devices.

Accordng to official data, Ukraine spends no less on education than European countries (about $4 \%$ of GDP) (State Statistics Service of Ukraine, 2021). Ukrainians also are one of the most educated nations; it ranks $10-12$ in the world in terms of enrollment in higher education. Highe education is received by $79 \%$ of people between the ages of 20 and 26 (OECD, 2021b). Based on the population, Ukraine has an average of 6.35 universities per 1 million people. This number of universities looks excessive compared to European countries; there are 288 universities in Ukraine, but none has risen above the 400th line in the global ranking of educational institutions of the world according to QS World University Rankings (QS, 2021). The current situation testifies to the ineffectiveness of spending within the educational system, a high level of migration of educated youth from Ukraine, and the inconsistency of the structure of the employment market with trends in higher education. These aspects were not considered within the framework of this study, however, since they require separate and detailed analysis and will be investigated in future works.

\section{REFERENCES}

Abdelmajied, F., \& Safijllin, L.N. (2018). Approaches for measuring human capital and its effect on economic growth. Opcion, 34, 957-978.

Aganbegyan, A.G. (2017). Human capital and its main component is the "knowledge economy" as the main source of socioeconomic growth. Economic strategies, 3. https://stolypin.institute/novosti/chelovech eskij-kapital-i-ego-glavnayasostavlyayushhaya-sfera-ekonomiki-znanijkak-osnovnoj-istochnik-sotsialno- 
ekonomicheskogo-rosta

Alsan, M., Bloom, D. E., \& Canning, D. (2006). The effect of population health on foreign direct investment inflows to low- and middleincome countries. World development, 34(4), 613-630. https://doi.org/10.1016/j.worlddev.2005.09. 006

Beley, N., Kudlatsky, Ya., \& Kovalev, A. (2020). From walls to quality: the beginning of a long journey. https://zn.ua/ukraina-19912020/ot-sten-k-kachestvu-nachalodlinnoho-puti-.html

Bieliński, T. (2016). Innovativeness and human capital as a main source of competitiveness of Chinese economy. Forum Scientiae Oeconomia, 4(1), 21-31.

Contreras-Reyes, J.E., \& Hernández-Santoro, C. (2020). Assessing Granger-Causality in the Southern Humboldt Current Ecosystem Using Cross-Spectral Methods. Entropy, 22, 1071. doi:10.3390/e22101071

Friedman, O., \& Trines, S. (2019). Education in Ukraine. https://wenr.wes.org/2019/06/education-inukraine

Gorelova, G., Pankratova, N., \& Borisova, D. (2019). Problems of interregional integration, cognitive modeling. IFACPapersOnLine, 52, 25, 168-173. https://doi.org/10.1016/j.ifacol.2019.12.467

Habibov, N. (2016). Effect of corruption on healthcare satisfaction in post-soviet nations: A cross-country instrumental variable analysis of twelve countries. Social Science \& Medicine, 152, 119-124. https://doi.org/10.1016/j.socscimed.2016.01 .044 .

High Fliers Research. (2021). The Graduate Market in 2021.

https://www.highfliers.co.uk/download/202 1/graduate_market/GM21-Report.pdf

Interfax. (2021). Zelensky signs decree to increase minimum wage for doctors. https://en.interfax.com.ua/news/general/75 0905.html

Ismayilzade, A. A., Guliyeva, S., Teymurova, V., Azizova, R., \& Alishova, C. (2021). The impact of Covid-19 on the quality of human capital for the economic development of Azerbaijan. Journal of Eastern European and Central Asian Research, 8(1), 26-39. https://doi.org/10.15549/jeecar.v8i1.639

Karaçor, Z., Güvenek, B., Ekinci, E., \& Konya, S. (2019). Panel estimation for the relationship between education expenditure and economic growth for OECD countries. Forum Scientiae Oeconomia, 6(2), 7-20. https://doi.org/10.23762/FSO_VOL6NO2_18_1

Kupets, O. (2016). Education-job Mismatch in Ukraine: Too Many People with Tertiary Education or Too Many Jobs for Low-skilled? Journal of Comparative Economics, 44, 125147.

https://doi.org/10.1016/j.jce.2015.10.005

Márti, S.C. (2004). Investing in health for economic development. https://www.who.int/macrohealth/action/si ntesis15novingles.pdf

Megits, N., Neskorodieva, I., \& Schuster, J. (2020). Impact assessment of the COVID-19 on trade between Eastern Europe and China. Journal of Eastern European and Central Asian Research, 7(3), 385-399. https://doi.org/10.15549/jeecar.v7i3.579

OECD. (2001). The Well-being of Nations. The Role of Human and Social Capital. https://doi.org/10.1787/9789264189515-en

OECD. (2021a). GDP per hour worked. https://data.oecd.org/lprdty/gdp-per-hourworked.htm

OECD. (2021b). Population with tertiary education. https://data.oecd.org/eduatt/populationwith-tertiary-education.htm

Our World In Data. (2021). Human Capital Index vs. GDP per capita.

https://ourworldindata.org/grapher/humancapital-index-vs-gdp

Pirtskhalaishvili, D., Paresashvili, N., \& Kulinich, $T$. (2021). The gender aspects of career development and leadership in organizations. Journal of Eastern European and Central Asian Research, 8(2), 255 - 266. https://doi.org/10.15549/jeecar.v8i2.654

Psacharopoulos, G., \& Patrinos, H.A. (2018). Returns to Investment in Education. A Decennial Review of the Global Literature. 
Policy Research Working Paper 8402.

QS. (2021). QS World University Rankings. https://www.topuniversities.com/university -rankings/world-university-rankings/2021

Romaniuk, P., \& Semigina, T. (2018). Ukrainian health care system and its chances for successful transition from Soviet legacies. Globalization and health, 14(1), 116. https://doi.org/10.1186/s12992-018-0439-5

State Statistics Service of Ukraine. (2021). Statistical Information. http://www.ukrstat.gov.ua/

The World Bank Group. (2020). Investing in Human Capital a Top Priority for Ukraine Amid Pandemic, says World Bank. https://www.worldbank.org/en/news/pressrelease/2020/09/16/investing-in-humancapital-a-top-priority-for-ukraine-amidpandemic-says-world-bank

The World Bank Group. (2021a). Human Capital Project. https://www.worldbank.org/en/publication/ human-capital

The World Bank Group. (2021b). GDP per capita (current US\$). https://data.worldbank.org/indicator/NY.GD P.PCAP.CD

Trovato, M.R. (2020). Human Capital Approach in the Economic Assessment of Interventions for the Reduction of Seismic Vulnerability in Historic Centres. Sustainability, 12, 8059. doi:10.3390/su12198059

World Economic Forum. (2013). The Human Capital Report 2013. http://reports.weforum.org/human-capitalindex-2013/\#=

Zelinska, H., Andrusiv, U., \& Simkiv, L. (2020). Knowledge economy: trends in the world and analysis of Ukraine. Journal of Eastern European and Central Asian Research, 7(1), 104-113. https://doi.org/10.15549/jeecar.v7i1.325

Zhao, Y.L. (2020). Innovation, Demand for Skills, and Productivity Growth. http://econweb.umd.edu/ zhao/files/JMP_z hao.pdf

Zheng, L., \& Lu, Y. (2020). Health Human Capital Investment and Economic Growth.
Technium Social Sciences Journal, Technium Science, 8(1), 229-248.

\section{ABOUT THE AUTHORS}

Andrii Zolkover, email: zolkover.andrey@gmail.com

Andrii Zolkover, $\mathrm{PhD}$ in Economics, Associate Professor of the Department of Finance and the financial and economic security, Kyiv National University of Technologies and Design, Kyiv, Ukraine.

Anastasiia Kaplina, $\mathrm{PhD}$ in Economics, Associate Professor of the Department of Management and Information Technologies, Kherson State Agrarian and Economic University, Kherson, Ukraine.

Olena Loboda, PhD in Technology, Associate Professor of the Department of Management and Information Technology, Kherson State Agrarian and Economic University, Kherson, Ukraine.

Natalia Kyrychenko, $\mathrm{PhD}$ in Economics, Associate Professor of the Department of Management and Information Technologies, Kherson State Agrarian and Economic University, Kherson, Ukraine.

Nataliia Chopko, PhD in Economics, Associate Professor of the Department of Management, Ivan Franko National University of Lviv, Lviv, Ukraine. 